\title{
Segmental zoster paresis of the lower extremity: Case report
}

\author{
Alt ekstremitenin segmantal zoster parezisi: Olgu sunumu
}

\author{
(1) Selin BALTA, 1 @ Gül KÖKNEL TALU²
}

\begin{abstract}
Summary
Herpes Zoster $(\mathrm{HZ})$, is a segmental vesicular eruption, pain, and sensorial symptoms. Segmental motor weakness can rarely be seen as a complication of $\mathrm{HZ}$. Here we present two cases of motor paresis associated with herpes zoster, case 1 was L2 and L3 segmental motor paresis with femoral neuropathy and case 2 was $L 5$ and $\mathrm{S} 1$ segmental motor paresis with sensorial ganglion involvement. In both cases after electrotherapy, exercise program, and medication for pain there were no motor weakness and pain. Zoster motor paresis is a rare complication that responds to treatment and physicians should be careful about its presence in clinical follow-up.
\end{abstract}

Keywords: Postherpetic neuralgia; segmental zoster paresis; zona.

\begin{abstract}
Özet
Herpes Zoster (HZ), segmental veziküler döküntü, ağrı ve duyusal semptomlar ile karakterizedir. Segmental motor güçsüzlük, nadiren HZ'nin bir komplikasyonu olarak görülebilir. Burada herpes zoster ile ilişkili iki motor parezi olgusunu sunuyoruz. Olgu $1 \mathrm{~L} 2$ ve L3 segmental motor pareziye eşlik eden femoral nöropati, olgu 2 ise duyusal ganglion tutulumu ile birlikte L5 ve S1 segmental motor parezi idi. Elektroterapi, egzersiz programı ve ağrı kesici ilaç tedavisinden sonra her iki vakada motor güçsüzlük ve ağrıda belirgin iyileime görüldü. Zoster motor parezi, tedaviye yanıt veren nadir bir komplikasyondur ve hekimler klinik takipte olası varlığına dikkat etmelidir.
\end{abstract}

Anahtar sözcükler: Postherpetik nevralji; segmental zoster parezi; zona.

\section{Introduction}

The Varicella-Zoster virus is a herpes virus that causes chickenpox in childhood. On the resolution of the primary infection, residual provirus segments travel by sensory nerves and stay dormant in the cranial or dorsal root ganglion. Herpes Zoster $(\mathrm{HZ})$ is a common vesicular eruption and is characterized by segmental rash, pain, and sensorial symptoms, which is caused by reactivation of the varicella-zoster virus. ${ }^{[1]}$ Zoster occurs during the lifetime of $10 \%$ to $20 \%$ of all people, with an incidence in the general population of approximately 3 to 5 per 1000 annually. The neurological complications of $\mathrm{HZ}$ include aseptic meningitis, myelitis, encephalitis, Guillain-Barre syndrome, stroke, and peripheral neuropathy. ${ }^{[2]}$

A rare neurologic complication of $\mathrm{HZ}$ is segmental motor weakness, which was first described by
Broadbent in $1866 .^{[3]}$ Segmental zoster paresis has been reported in $5 \%$ to $30 \%$ of cases in electrophysiological and clinical studies. ${ }^{[4,5]}$ It is believed that motor involvement may develop due to the extension of the inflammation from the dorsal root ganglia to the ventral roots. However, the exact pathology is still unknown. ${ }^{[6]}$ Many of the clinical findings in $\mathrm{HZ}$, including polyradiculopathy and motor weakness, can be explained as the involvement of the central nervous system, in addition to involvement of the dorsal root ganglion. The basic pathological neural reaction is axonal degeneration, with some degree of secondary segmental demyelination. ${ }^{[7]}$

In addition to standard evaluation, various diagnostic evaluations can be mandatory for clinical presentations. Electromyography is helpful in zoster paresis as it helps to establish the presence of

'Department of Algology, University of Health Sciences, Konya Training and Research Hospital, Konya, Turkey

${ }^{2}$ Division of Algology, Department of Anestesiology and Reanimation, İstanbul University, Istanbul Faculty of Medicine, İstanbul, Turkey

Submitted: 24.11.2020 Accepted after revision: 20.01.2021 Available online date: 04.02.2021

Correspondence: Dr. Selin Balta. Sağlık Bilimleri Üniversitesi, Konya Eğitim ve Araştırma Hastanesi, Algoloji Kliniği, Konya, Turkey.

Phone: +90 - 532 - 5002333 e-mail: selinaa01@yahoo.com

C) 2021 Turkish Society of Algology 
neurogenic lesions and aids in prognosis in terms of the estimated time for recovery. ${ }^{[8]}$

This article presents two cases of motor paresis associated with herpes zoster.

\section{Case Reports}

Case 1 - A 73 years old diabetic male patient was referred from the department of dermatology to our pain clinic with a complaint of sharp, burning pain and itching that started after the skin eruptions of $\mathrm{HZ}$ on his left lower extremity, persisting for three months. He had received antiviral therapy but not the varicella-zoster vaccine.

The patient complained of severe neuropathic pain (NRS: 10) (LANSS: 14) on his L2, L3, and L4 dermatomes. He described the difficulty of walking and climbing the stairs for the past month. No additional symptoms were found in comprehensive neuromuscular system symptoms questioning. He had been receiving a combination therapy of oral acyclovir treatment since the second day of the painful zoster eruptions and was prescribed gabapentin $600 \mathrm{mg}$ twice a day, a tricyclic antidepressant - amitriptyline $10 \mathrm{mg}$, paracetamol and codeine.

Skin examination only showed significant hyperpigmented macular lesions on the left anterior thigh. Neurological examination revealed a muscle strength of $3 / 5$ on his left quadriceps muscle. Left patellar tendon reflex was hypoactive. Left L2, L3, and L4 dermatomes were hyperalgesic. Complete cranial nerve examination was within normal limits. Examination of the upper extremities and the right leg revealed no motor or sensory deficits. There was no upper motor neuron or meningeal irritation findings. The patient was hospitalized into our pain clinic for further evaluation of motor paralysis and management of his pain.

Laboratory tests of vitamin B12, folate levels, renal functions, liver enzymes, hemogram, prostate-specific antigens, thyroid function tests, serology of syphilis, viral hepatitis, and HIV were all normal.

In the lumbar spinal Magnetic Resonance Imaging (MRI), bilateral L5 radix compression due to foraminal stenosis was detected. There was no pathology in the lumbar plexus and cranial MRI. Needle electromyography showed fibrillations and positive sharp waves with polyphasic and motor unit potentials in long durations in the left vastus medialis and lateralis, rectus femoris, and iliopsoas. The nerve conduction study showed left $\mathrm{n}$. femoralis motor response and $\mathrm{n}$. saphenus sensorial response as absent. EMG showed previous bilateral involvement of $L 5$ roots and neurogenic involvement in the subacute period, accompanied by active denervation in the left myotomes of $L 2-L 3$, a more severe effect in the innervated muscles of the femoral nerve and there was also electrophysiological evidence of ongoing reinnervation.

With these clinical finding, the diagnosis was established as segmental zoster paresis.

Muscle-strengthening exercises, an application of 20 sessions of TENS (Transcutaneous electrical nerve stimulation), topical capsaicin, and tramadol of 300 $\mathrm{mg} /$ day were added to his ongoing medical treatment. The patient was discharged with no pain complaints (NRS: 0) (LANSS: 5).

After 6 months of the home exercise program, we found that there was no motor weakness, but the patient complained of mild pain (NRS: $3 / 10$ ). The control EMG study showed the findings of reinnervation.

Case 2 - An eighty years old male patient with diabetes mellitus and hypertension was referred to our pain clinic for zoster associated pain from a dermatology clinic. The patient was suffering from burning and a shock like pain that had started one week before developing skin eruptions. He received valacyclovir treatment on the second day after zoster eruptions. The patient complained of severe neuropathic pain (NRS: 8/10) (LANSS: 12) and weakness at the left lower extremity. He did not complain of any additional musculoskeletal and neurological symptoms. He had not received the varicella-zoster vaccine.

Skin examination showed significant hyperpigmented macular lesions on the left gluteal and posterior thigh. Neurological examination revealed muscle strength of $4 / 5$ on the left gluteus maximus muscle, $2+/ 5$ on the gluteus medius, $3+/ 5$ on the hamstrings and ankle plantar flexors, and 2-/5 ankle dorsiflexors. His left achilles tendon reflex was hypoactive. The 
left L5, S1, S2, and S3 dermatomes were hyperalgesic. Complete cranial nerve examination was within normal limits. Examination of the upper extremities and the right leg revealed no motor or sensory deficits. There were no upper motor neuron nor any meningeal irritation findings. The patient was hospitalized into the pain clinic for further evaluation for motor paralysis and for pain management.

Laboratory tests of hepatitis serology, vitamin B12 and folate levels, varicella serology, urines, thyroid functional tests, liver enzymes, and prostate-specific antigen were all normal. There were no pathologies in the cranial, lumbar spinal, and lumbar plexus MRIs.

With these clinical findings MRI, EMG and laboratory tests, the diagnosis was established as being segmental zoster paresis.

A combination of muscle-strengthening exercises, TENS application (20 sessions), topical capsaicin, pregabalin of $150 \mathrm{mg} /$ day, and paracetamol codeine was started. The patient was discharged with mild pain (NRS: 2) (LANSS: 10). After 6 months of the home exercise program, we found that there was no motor weakness nor any pain. Furthermore, the control EMG study showed the findings of reinnervation.

\section{Discussion}

The most common complication of $\mathrm{HZ}$ is postherpetic neuralgia and chronic pain syndrome predominantly presenting with pain and allodynia in the affected region persisting for months or years after the lesions have healed. Meningoencephalitis, meningoradiculitis, cerebritis, myelopathy, retinal necrosis, vasculopathy of cerebral arteries present with an ischemic attack, and chronic headache can also be seen as neurological complications of $\mathrm{HZ}{ }^{[9]}$

Segmental zoster paresis is rare. Evaluating the patients in the case discussion we observe that both patients were at an advanced age. Case 1 had quadriceps weakness; case 2 had gluteal muscles and ankle flexors weakness. Although zoster-associated motor paresis is rare, it is more likely to occur in older patients and proximal muscle groups. ${ }^{[10,11]}$ Diabetes mellitus (DM) has been recently found to be a risk factor for the development of zoster-associated motor paresis, recently. ${ }^{[12]}$ Both of the cases had a concomitant disease like DM. In addition, both patients had macular hyperpigmented lesions. Case 1 's lesions were on the upper anterior leg and thigh muscle paresis, and Case 2's lesions were on the left gluteal and posterior thigh. In several studies, segmental motor paresis and dermatomal distribution of skin eruptions were in the same areas ${ }^{[9,12,13]}$ but this is not a rule. ${ }^{[10]}$

Both cases had muscle weakness that started three (Case 1) and two months (Case 2) after the skin eruption of HZ. Development of motor paresis generally occurs during the first two weeks of zoster infection. [14] However, motor paresis has been shown to develop even 1 month after the skin rash has healed. ${ }^{[15]}$

EMG findings of Case 1 showed femoral neuropathy with axonal involvement. Mononeuropathy in electrophysiological studies conducted in $\mathrm{HZ}$ limb paralysis was reported in recent studies. ${ }^{[16,17]}$ Full and nearcomplete motor recovery, weeks and even months after the healing of skin lesions were revealed in a review study ${ }^{[18]}$ Both of the cases had a full motor recovery that was revealed at the follow-up polyclinic visits in accordance with the literature.

Neither case had been vaccinated. Vaccination for Herpes Zoster would reduce the risk of motor paresis related to HZ. ${ }^{[19]}$ Mondelli et al. ${ }^{[20]}$ showed that antiviral therapy could prevent motor involvement associated with $\mathrm{HZ}$ however, both of the cases had acyclovir therapy.

Although it is very rare, segmental zoster paresis must be considered in diagnosis and differential diagnosis in patients with advanced age and DM, and without vaccination who especially suffer from neuropathic pain with or without eruptions.

Motor paresis is a rare complication of common zoster infection, and can sometimes be underdiagnosed. Keeping in mind the possible diagnosis of motor paresis in evaluating patients with $\mathrm{HZ}$, a differential diagnosis can be revealed by electromyographic studies after clinical questioning and examination. Multimodal treatment, medical neuropathic pain treatment, supplemented with muscle-strengthening exercise, and TENS applications, helps to reduce symptoms, sequels, and increase the quality of life. 
Conflict-of-interest issues regarding the authorship or article: None declared.

\section{Peer-rewiew: Externally peer-reviewed.}

\section{References}

1. Denny-Brown D, ADAMS RD, FITZGERALD PJ. Pathologic features of herpes zoster: a note on geniculate herpes. Archives of Neurology \& Psychiatry. 1944;51(3):216-31.

2. Gnann JW, Jr., Whitley RJ. Clinical practice. Herpes zoster. The New England journal of medicine. 2002;347(5):340-6.

3. Broadbent WH. Case of herpetic eruption in the course of branches of the brachial plexus, followed by partial paralysis in corresponding motor nerves. British medical journal. 1866;2(304):460.

4. Ragozzino MW, Melton LJ, $3^{\text {rd }}$, Kurland LT, Chu CP, Perry HO. Population-based study of herpes zoster and its sequelae. Medicine. 1982;61(5):310-6.

5. Dumitru D, Amato AA, Zwarts MJ. Electrodiagnostic medicine: Hanley \& Belfus Philadelphia; 2002.

6. Fabian V, Wood B, Crowley P, Kakulas B. Herpes zoster brachial plexus neuritis. Clinical neuropathology. 1997;16(2):61-4.

7. Braverman DL, Ku A, Nagler W. Herpes zoster polyradiculopathy. Archives of physical medicine and rehabilitation. 1997;78(8):880-2.

8. Merchut M, Gruener G. Segmental zoster paresis of limbs. Electromyography and clinical neurophysiology. 1996;36(6):369-75.

9. Nagel MA, Gilden D. Neurological complications of VZV reactivation. Current opinion in neurology. 2014;27(3):356.

10. Teo HK, Chawla M, Kaushik M. A rare complication of herpes zoster: segmental zoster paresis. Case reports in medi- cine. 2016;2016.

11. Murphy P. Case report on motor neuropathy associated with herpes zoster. The Journal of the Kentucky Medical Association. 2005;103(7):303-6.

12. Ragozzino M, Melton L, Kurland L. Herpes zoster and diabetes mellitus: an epidemiological investigation. Journal of chronic diseases. 1983;36(7):501-5.

13. Stalnaker LD, Goebel M, Lynne J. Post-herpetic Paresis of the Lower Extremity: An Unusual Complication of Shingles. Marshall Journal of Medicine. 2016;2(2):27.

14. Thomas JE, Howard FM. Segmental zoster paresis-a disease profile. Neurology. 1972;22(5):459-.

15. Martić V. Recurrent herpes zoster with segmental paresis and postherpetic neuralgia. Vojnosanitetski Pregled. 2014;71(2):214-7.

16. Gopal K, Sarvani D, Raju PK, Rao GR, Venkateswarlu K. Herpes zoster motor neuropathy: A clinical and electrophysiological study. Indian Journal of Dermatology, Venereology, and Leprology. 2010;76(5):569.

17. Reda H, Watson JC, Jones Jr LK. Zoster-associated mononeuropathies (ZAMs): A retrospective series. Muscle \& Nerve. 2012;45(5):734-9.

18. Kawajiri S, Tani M, Noda K, Fujishima K, Hattori N, Okuma Y. Segmental zoster paresis of limbs: report of three cases and review of literature. The Neurologist. 2007;13(5):313-7.

19. Oxman M, Levin M, Johnson G, Schmader K, Straus S, Gelb $L$, et al. A vaccine to prevent herpes zoster and postherpetic neuralgia in older adults. New England Journal of Medicine. 2005;352(22):2271-84.

20. Mondelli M, Romano C, Passero S, Della Porta P, Rossi A. Effects of acyclovir on sensory axonal neuropathy, segmental motor paresis and postherpetic neuralgia in herpes zoster patients. European Neurology. 1996;36(5):288-92. 